\title{
INTEGRATED BALANCED FERTILISER MANAGEMENT IN SOIL HEALTH REJUVENATION FOR A SUSTAINABLE OIL PALM CULTIVATION: A REVIEW
}

\section{SHAMALA SUNDRAM*; LEE PEI LEE ANGEL* and SALWA ABDULLAH SIRAJUDDIN*}

\begin{abstract}
Oil palm cultivation occupies a large planting area in Malaysia and is one of the most profitable commercial crops contributing to unprecedented socio-economic development in the country. The crop, however, requires high uptake of macronutrients and some relevant amounts of micronutrients largely supplied by agrochemical-based fertilisers. The overuse of fertilisers endangers the ecosystem with possible effect on the environment especially on the soil health and its microbial diversity. With oil palm replanting in its fourth generation, the practice needs to be sustainable yet economic without compromising the yield and this is the challenge being faced by the industry. This article discusses the importance of fertilisers, types of fertilisers (inorganic, organic and microbial-based products) and balancing the effects with agrochemicalbased fertilisers in oil palm plantations through balanced integrated fertiliser application. This could be one of the most effective sustainable strategies in improving the soil health by enhancing the biodiversity of microorganisms and community composition in soil towards a balanced ecosystem. Sustainable soil health management system has the capacity to produce higher yields while maintaining if not improving the soil health. Finally, the article addresses future recommendations that highlight soil health which is also the current focus of modern agriculture.
\end{abstract}

Keywords: soil health, fertiliser, integrated fertiliser application, oil palm, sustainable cultivation.

Date received: 8 July 2019; Sent for revision: 8 July 2019; Received in final form: 25 August 2019; Accepted: 27 August 2019.

\section{INTRODUCTION}

Soil is a dynamic system that occupies one of the most biologically diversified habitats on the planet. It is an unconsolidated, thin, variable layer comprising of mineral and organic materials, is more than usual to be biologically active covering most land surface on the earth (Singer and Munns, 2002). Mankind has been dependent on soil for many centuries to fulfil the need for food, fibre, livestock feed and

\footnotetext{
Malaysian Palm Oil Board,

6 Persiaran Institusi, Bandar Baru Bangi,

43000 Kajang, Selangor, Malaysia.

E-mail: shamala@mpob.gov.my
}

other industrial essentials, e.g. biofuels (Singh and Ryan, 2015). As a result, agriculture intensification occurred with increasing global demand for food, feed, timber and fuel which also eventually led to the massive conversion of natural ecosystems to agroecosystems (Guillaume et al., 2016). Agriculture then flourished with enhanced agronomic practices / technologies such as mechanisation, high yielding breeds, disease-resistant crops and agrochemical fertilisers. While the focus has always been on the enhanced crop yields, increased awareness to soil health became apparent when limited land for production was realised (Singh and Ryan, 2015). This brought in the realisation on sustainable cropping practices that still allows high yielding without 
compromising soil health and quality. For the past century, evaluating quality and soil health has been of interest due to the high dependence on soil for various human needs (Bender et al., 2016; Doran and Zeiss, 2000; Singh and Ryan, 2015). One of the main indicators of soil health is the soil organisms and their diversity. It has been well established that soil biodiversity promotes simultaneous multiple ecosystem functions as it is a habitat for various organisms that contribute to different functions in the soil (Bender et al., 2016; Kibblewhite et al., 2008; Singh and Ryan, 2015). Doran and Zeiss (2000) defined soil health being represented as one vital living and dynamic system whereby it sustains productivity of plant and animal, improves water and air quality, and finally promotes health for plant and animal. Some of the key functions of a healthy soil include its ability to maintain biological productivity, recycling and storing of water and nutrients, platform for decomposition of organic matter, inactivates toxic compounds, able to defend against pathogens and retains water quality (Singh and Ryan, 2015).

The annual production of palm oil in 2018 was 19.52 million tonnes of crude palm oil (CPO) with export earnings of oil palm products estimated at RM 65.12 billion in Malaysia (Kushairi et al., 2019). For decades, Malaysia has held the title as one of the most productive palm oil producers in the world (Awalludin et al., 2015). The golden crop currently is entering into its fourth generation of replanting. For many years, planters' concern have always been focused above-ground; the crop. To complement this, research throughout the years has been directed on the improvement of the crop itself through advanced breeding materials that focuses on higher yield, shorter palms and higher percentage of oil extraction. On agronomy, research was conducted on external factors such as fertilisers through the various trials on different fertiliser application to achieve optimum yields (Goh and Härdter, 2003). However, with the recent mind set change of current planters, more emphasis is being directed into the well-being of the environment, particularly on soil component in order to create sustainable crop cultivation. Therefore, this article discusses the importance of soil health, whereby it highlights the necessity of having high quality soils in order to sustain the livelihood of oil palm cultivation in Malaysia.

Progressively, there is evidence for widespread degradation of agricultural soils in the form of erosion, atmospheric pollution, extensive soil cultivation, land clearing, overgrazing, loss of organic matter, contamination, compaction, increased salinity and other forms of harmful effects which causes the degradation in soil health (Singh and Ryan, 2015). Furthermore, oil palm along with many other agriculture crops requires large quantities of fertiliser annually to sustain high crop yields and often the nutrients are insufficient to sustain the plant growth. It has been argued that this degradation is occurring more rapidly than subtly due to poor soil management which also directly affects production in agriculture (Khasanah et al., 2015; Sahat et al., 2016). Based on the paper by Kibblewhite et al. (2008), soil health is described to be influenced by fertiliser application. Appropriate and careful fertiliser application can reduce the rapid degradation of soil in the form of nutrient and organic matter depletion (Kibblewhite et al., 2008; Singh and Ryan, 2015).

Soil health corresponds directly to soil management and is fundamental in all agricultural systems. Understanding the fertility of the soil is a complex process with numerous compounding factors affecting and influencing the system. One such factor is the nutrient component in the soil. Soil health along with other factors, such as the biotic component, is very much influenced by nutrients. The dynamics will be affected by recycling of nitrogen $(\mathrm{N})$ and phosphorus $(\mathrm{P})$ to, from and within the soil system. The shortage of nutrients to the palms might result in severe damage to crop health. There are few essential elements that are required for proper growth of oil palm and their deficiencies with diagnostic symptoms was described by McCauley (2009) as shown in Table 1. However, not all deficiency gave rise to symptoms in foliage.

\section{TABLE 1. NUTRIENT DEFICIENCY SYMPTOMS}

(McCauley, 2009)

\begin{tabular}{ll}
\hline Elements & Distinct symptoms \\
\hline Nitrogen $(\mathrm{N})$ & Chlorosis \\
Potassium $(\mathrm{K})$ & Orange spotting/orange blotch \\
Magnesium $(\mathrm{Mg})$ & Orange frond \\
Boron $(\mathrm{B})$ & Hook leaf/crinkle leaf \\
Copper $(\mathrm{Cu})$ & Mid-crown chlorosis \\
Zinc $(\mathrm{Zn})$ & Yellow, shortened narrow pinnae \\
\hline
\end{tabular}

This article will discuss the interactions and repercussions produced by one of the oldest agricultural components, i.e. fertiliser and possibility of integrating different fertiliser types to compromise each other in order to achieve good crop yields with possibly minimal effects on soil health. It caters to the agriculturists in Malaysia who focus on efficient means to improve the quality of the soils for oil palm cultivation in the future.

\section{DETERIORATION IN SOIL HEALTH}

Deterioration of the soil quality often caused by poor agricultural practices and also due to intensive cultivation. Soil is a non-renewable resource that is vulnerable to degradation, depending on the factors 
and complexity of interactions between the processes throughout the years (Lal, 2015). Soil erosion is one of the factors related to soil degradation. With respect to Malaysia being one of the largest producers of palm oil, suitable land in Malaysia for oil palm planting is exhausted leading to alternative by planting on marginal areas such as hilly and sloping lands (Afandi et al., 2017). High rainfall occurs and leads to soil erosion which subsequently results in leaching of soil nutrients, organic matter and soil biota, loss of soil structure and changes in infiltration rates (Lord and Clay, 1999). Studies also showed that the soil degradation of oil palm in the interrows was higher than in the row as there was a reduction of carbon $(\mathrm{C})$ content and increased in older oil palm plantation (Guillaume et al., 2016). Removal of nutrients by fresh fruit bunches (FFB), immobilisation of nutrients in trunk and roots are several contributing factors in the soil degradation as oil palm continuously consumes the nutrients from the soil for its growth and production of FFB.

Intensive use of machinery for crop evacuation, fertiliser application, pests and diseases control may cause degradation of soil health by continuous of traffic on harvesting path. Continuous compaction on the soil reduces porosity and aeration, limiting water and nutrient availability to plants and also increases the risk of resistance to root penetration (Yahya et al., 2010). This may lead to poor crop yields and over time, increases the pollution on land. Additionally, survey on fuel consumption in mechanisation practices on several oil palm plantations in Malaysia shows that almost 2.6 GJ ha ${ }^{-1} \mathrm{yr}^{-1}$ of diesel consumption, which is equivalent to greenhouse gas (GHG) emission of approximately $133 \mathrm{~kg} \mathrm{CO}_{2}-$ eq ha $^{-1} \mathrm{yr}^{-1}$ (Azwan et al., 2016). The main objective of most plantations is to cultivate healthy palm and to produce optimum FFB yield. Depreciation of soil health is an issue that is of highest concern due to the fact that oil palm is one of the major plantation crops in South-east Asia. In order to achieve and sustain a good palm nutritional status with high yield, application of fertilisers is necessary. The removal of nutrients by the palm exceeding input of fertiliser increases the risk of nutrient depletion and is considered as unsustainable agricultural practice and more commonly is associated with low yields. Regular adequate fertiliser usage is associated with small but consistent increases in soil organic matter $(\mathrm{SOM})$ as a result of increased root biomass despite the misconception that $\mathrm{N}$ use leads to decreased SOM (Singh and Ryan, 2015). Therefore, the role of fertiliser is important to replace the nutrient loss during soil erosion or extensively being taken up by the crops. This process is known as the rejuvenation of soil health. However, we cannot just focus in using one fertiliser type. Overusing of chemical fertilisers alone in the long-term will cause adverse effects towards the soil fertility and other environmental issues (Bender et al., 2016; Singh and Ryan, 2015). If we only focus on the usage of organic and biofertilisers, the plantations might be seen as an area of dumping ground for organic waste and the nutrients supplied are definitely insufficient for the oil palm growth and productivity. A balanced application of fertilisers is crucial in order to create a sustainable environment and maintaining a good soil health with a balance of nutrients and soil biodiversity through the integration of biofertilisers. Therefore, integrating soil health and management strategies is the way forward to achieve this.

\section{IMPORTANCE OF FERTILISERS IN OIL PALM CULTIVATION}

Every crop has its specific nutrient needs. Characteristic of a crop influences the total nutrient needs, timing and amount of nutrients can be obtained from the soil. All these factors are important to note in the integrated plant nutrient management. Many researches have been conducted on the nutrient requirement of oil palm, and they particularly need large quantities of potassium $(\mathrm{K})$, nitrogen $(\mathrm{N})$, phosphorus $(\mathrm{P})$, magnesium $(\mathrm{Mg})$ and boron (B). In peat soils, fertilisation with zinc $(\mathrm{Zn})$ and copper $(\mathrm{Cu})$ is essential and specific deficiencies will lead to visible foliar symptoms (Broeshart et al., 1957). Fertiliser is one of the key components of oil palm cultivation which primarily comprises of inorganic chemicals with the cost of fertiliser rising to $30 \%$ or more of the production cost (Goh et al., 2011). Optimising the crop's use efficiency of fertiliser-supplied nutrients is critical for this process (Oberthür and Donough, 2017). Oil palm cultivation requires significant amount of fertiliser to supplement the natural supply of soil nutrient, build up soil fertility and to compensate nutrients taken up by harvested products or lost by unavoidable leakages to the environment in order to maintain good soil conditions for optimum crop production. It is estimated that nutrients removed by oil palms producing $25 \mathrm{t} \mathrm{ha}^{-1} \mathrm{FFB} \mathrm{yr} \mathrm{r}^{-1}$ are 192, 11, 209, 36 and $71 \mathrm{~kg} \mathrm{ha}^{-1} \mathrm{yr}^{-1}$ of N, P, K, Mg and Ca, respectively (Goh and Härdter, 2003).

The effects of N, P, K and Mg on the yield of FFB were compared between three different fertiliser experiments (Woittiez et al., 2017). For N, P and $\mathrm{K}$, respectively compared with no fertiliser with average applications, showed the range of nutrient use efficiency (NUE) at different levels of fertiliser use were 0-45, 0-20 and 15-90 kg fruit bunches per $\mathrm{kg}$ nutrient $\mathrm{ha}^{-1} \mathrm{yr}^{-1}$. Nevertheless, NUE became negative when the amount of nutrients applied was increased from average to higher quantity. The NUE at maximum fertiliser rates were 13,0 and $8 \mathrm{~kg}$ fruit bunches per $\mathrm{kg}$ nutrient ha ${ }^{-1} \mathrm{yr}^{-1}$ for $\mathrm{N}, \mathrm{P}$ and $\mathrm{K}$, respectively (Woittiez et al., 2017). Another study by 
Tarmizi and Mohd Tayeb (2006) also suggested that application of $4.2 \mathrm{~kg}$ ammonium sulphate palm $^{-1}$ $\mathrm{yr}^{-1}$ managed to produce $30 \mathrm{t} \mathrm{FFB} \mathrm{ha}^{-1}$. The above experiments are from some of the extensive field trials conducted to demonstrate the importance of fertilisers in the oil palm production and any limitation would result in compromised yield. Therefore, it is highly advocated that integration of fertilisers should be extensively explored before implementation.

\section{TYPES OF FERTILISERS}

The soil system and its functions are controlled by the nutrient availability in soil. The levels and transformation of nutrients are critical to soil health (Kibblewhite et al., 2008). Natural reserves of plant nutrients in the soil are largely in unavailable form towards plants (Chen, 2006). Soil is inhabited with species of flora and fauna that carry out various important functions, including biomass production, water storage and maintaining nutrient balance. The concept of balanced fertilisation is basically to ensure its application is at the optimum quantities and at the correct proportion through appropriate methods. Thus, this is hoped to improve physical, chemical and biological environment of the soil. Increase of plant yield can be achieved through the enhancement of NUE in plants to satisfy growing food demands and at the same time, reduces the environmental impacts of agriculture (Lobell, 2007). Reports also indicate that balanced use of fertilisers provides better resistance of plants towards drought, cold, insects, pest and diseases attack. Therefore, nutrient balance approach plays a key role in plant resistance to diseases while creating a sustainable oil palm plantation.

A fertiliser may be defined as an application of natural or synthetic materials such as N, P, and $\mathrm{K}$ compounds into the soil to enhance its capacity in order to support plant development. Fertiliser application has become necessary rather than optional for optimal growth of plants without compromising the plants' optimum yield potential (Doran and Zeiss, 2000; Kibblewhite et al., 2008; Singh and Ryan, 2015). Fertiliser comprises as one of the biggest components in the agricultural system, and typically can be classified into three types: chemical, also known as mineral fertilisers, organic fertilisers and biofertilisers (Chen, 2006; Singh and Ryan, 2015).

Chemical fertilisers are prepared from inorganic materials, derived either wholly or partially from a synthetic origin, while organic fertilisers are derived from the wastes or by-products of organisms which contain essential nutrients for plant growth. Biofertilisers on the other hand, are defined as preparations that contain living or latent cells of efficient/beneficial microorganisms assisting plants in the nutrient uptake (Bhardwaj et al., 2014; Mishra and Dash, 2014). These biofertilisers are able to mobilise nutritionally important elements from unavailable forms through biological processes. The recent surge of interest on biofertilisers is largely attributed to sustainable and green agriculture approaches (Bender et al., 2016). The use of these three fertilisers has its advantages and disadvantages and it is pertinent to integrate the advantages in achieving optimum performance by each of the fertiliser. The summary of common characteristics for the comparison of chemical, organic and biofertilisers are shown in Table 2.

TABLE 2. COMPARISON BETWEEN CHEMICAL, ORGANIC AND BIOFERTILISERS

\begin{tabular}{|c|c|c|c|}
\hline \multirow{2}{*}{ Characteristic } & \multicolumn{3}{|c|}{ Fertiliser } \\
\hline & Chemical & Organic & Biological \\
\hline Raw material & Non-renewable & Renewable & Renewable \\
\hline Nutrient release & Soluble and easily available & Balanced, slow and easily available & Very slow \\
\hline Nutrient effect & Direct, fast & Direct & Indirect \\
\hline Nutrient content & High & Low & Low \\
\hline Amount required & Lower & Higher & Higher \\
\hline Price & Lower & Higher & Higher \\
\hline Toxicity & $\begin{array}{l}\text { Overuse can cause } \\
\text { toxicity to the soil }\end{array}$ & $\begin{array}{l}\text { Decomposition of } \\
\text { harmful substance }\end{array}$ & $\begin{array}{l}\text { Decomposition of } \\
\text { harmful substance }\end{array}$ \\
\hline Soil structure & $\begin{array}{l}\text { Create residual effect } \\
\text { on soil texture }\end{array}$ & Soil structure improvement & Soil structure improvement \\
\hline Improvement of plant & $\begin{array}{l}\text { Promote growth and } \\
\text { root development }\end{array}$ & $\begin{array}{l}\text { Promote growth and } \\
\text { root development }\end{array}$ & $\begin{array}{l}\text { Promote growth and root } \\
\text { development }\end{array}$ \\
\hline Water retention & No & Increases soil water availability & Increases soil water availability \\
\hline Biodiversity in soil & $\begin{array}{l}\text { Deteriorates microbial } \\
\text { population }\end{array}$ & $\begin{array}{l}\text { Encourages growth of beneficial } \\
\text { microorganisms }\end{array}$ & $\begin{array}{l}\text { Enriches biodiversity of } \\
\text { microorganisms }\end{array}$ \\
\hline
\end{tabular}

Source: Chen (2006); Mishra and Dash (2014); Han et al. (2015). 


\section{Chemical Fertilisers}

Palms are highly influenced by appropriate fertiliser management for optimal FFB production and a balanced nutrition application elicits positive effects on the palm. With the expansion of oil palm planting into more diverse soil types, it is of absolute importance to design the fertiliser management according to the soil type. However, chemical fertilisers are preferred among the planters due to the fact that they are relatively inexpensive and the formulation packs more nutrients per unit weight. The nutrients in chemical fertilisers are generally soluble and available to the plant immediately, which creates a direct, fast improvement in plants. Therefore, fertilisers are prepared with high nutrient content that only requires small amount to be incorporated into the soil to achieve the desired optimum health (Mishra and Dash, 2014). In addition to this, the primary effect of the inorganic fertilisers is mainly aimed at the plant and its health with less concern on the soil health.

Overuse of chemical fertilisers will invite negative effects on the soil that includes changes in the physical, chemical and biological properties within the soil. This includes some of the common consequences on the soil as well as the soil properties such as leaching, soil $\mathrm{pH}$, shift in the microorganisms' biodiversity, reduction of beneficial insects, increase in diseases susceptibility, soil acidification/alkalisation, exchangeable $\mathrm{Ca}$ and loss of soil fertility (Kibblewhite et al., 2008; Mishra and Dash, 2014). Excessive usage of the reactive $N$ and $\mathrm{P}$, in alternate application also threatens the quality of the soil. This subsequently causes the loss of nitrate and $\mathrm{P}$ to water bodies eventually releasing high levels of ammonia and $\mathrm{N}$ oxides, which are GHG of 300 times more heat-trapping power compared to carbon dioxide (Velthof et al., 2014; Mole, 2014). Nitrogen fertilisers contribute to increase in soil acidity through nitrification process resulting from the release of hydrogen ions. Thus, this leads to the reduced microbial $\mathrm{N}$ immobilisation (Singh and Ryan, 2015). Plantations nowadays rely on machinery for fertiliser application. Study shows that $258 \mathrm{GJ}$ of input energy was required to produce $20 \mathrm{tha}^{-1} \mathrm{yr}^{-1}$ of FFB and $66 \%$ was dominated by application of chemical fertilisers (Azwan et al., 2016). Diesel fuel and machinery was identified as one of the factors impacting on environmental issue related to GHG emission such as carbon dioxide based on Life Cycle Analysis (LCA) conducted by the Malaysian Palm Oil Board (MPOB) previously (Zulkifli et al., 2010).

\section{Organic Fertilisers}

Fertilisers can be composed of organic matters, for example, carbon-based fertilisers which contains simple inorganic chemicals. Nutrient mobilisation from chemical and organic source is improved with the use of organic fertilisers as they enhance the soil biological activities. Organic fertilisers when applied at the right rates and frequency, can supply the nutrient requires by a crop. The balanced nutrient supply also aids in the development of plant health (Bender etal., 2016; Bhardwajetal., 2014). For instance, studies by Idris et al. $(2014 ; 2015)$ demonstrated the application of GanoCare ${ }^{\mathrm{TM}}$ formulated with macro and micronutrients, powdered with empty fruit bunches (EFB) and beneficial elements such as iron (Fe), manganese ( $\mathrm{Mn}), \mathrm{Cu}$ and silicon ( $\mathrm{Si}$ ) has increased the vegetative growth and reduced $63.5 \%$ risk of Ganoderma infection in oil palm seedlings.

Organic fertilisers are usually made from single ingredient that originated from a natural source and often complemented with inorganic fertilisers to meet nutritional requirements to the crops. Organic fertilisers can be derived from plant, animal or other mineral sources. This includes EFB, palm kernel cake (PKC), palm pressed fibre (PPF), palm oil mill effluent (POME), saw dust, rice straw and rice husk, and other materials that are agriculture waste. Basically, the concept of this type of fertiliser is to allow moisture and beneficial organisms to break down the content of fertiliser, thus conditioning the soil by slow release of organic ingredients throughout the years. Lim and Zaharah (2002) mentioned that the yield of FFB increase significantly by using EFB at $37.5 \mathrm{t} \mathrm{ha}^{-1} \mathrm{yr}^{-1}$ in oil palm field. In addition, soil exchangeable $\mathrm{K}, \mathrm{Ca}, \mathrm{Mg}$ and $\mathrm{pH}$ of the soil were improved too. Research by Abu Bakar et al. (2011) also proves that application of EFB as mulch and nutrient source to the oil palm field improves the soil fertility and sustains crop production for a long-term.

Therefore, increased use of organic fertilisers can reduce the pollution caused to the environment by agro-industrial and livestock farming while improving the nutrients availability to plants and as soil conditioner (Mishra and Dash, 2014). The use of organic fertiliser also improves soil organic content (SOC) with a larger yield trend along with contribution to the carbon sequestration by favouring root development (Yan and Gong, 2010). However, nutrient contents are invariably low for most of the organic fertilisers compared to chemical fertilisers. Large quantity needs to be used in order to obtain the comparable amount or effect that is provided by chemical fertilisers, which also includes macro and micronutrients that are essential for optimum growth and yield of all crops. The slow release of nutrient may result in nutrient deficiencies over a longer interval. Nutrient composition in organic fertilisers such as compost is also highly variable (Mishra and Dash, 2014), which may compromise plant growth in general. There is also the downside of using organic fertilisers where long-term or 
heavy applications to agricultural soils may result in salt, nutrient or heavy metal accumulation that may adversely affect plant growth, soil organisms, water quality, and animal and human health (Chand et al., 2006).

\section{Biofertilisers}

Biologically, soil ecosystems support one of the largest diversity of microbes (fungi, bacteria and algae), microfauna (protozoa) and mesofauna (arthropods and nematodes) (Bender et al., 2016; Neher, 2001). Soil microorganisms are also known to respond very quickly to the changes occurring in the soil environment which signifies their role in bioremediation and excellent candidates of bioindicators (Bhardwaj et al., 2014). Soil-microbeplant interaction is complex where the outcomes can affect the plant health and productivity and this ultimately leads to the balanced use of fertilisers. Taking into consideration of increasing awareness on soil health and sustainability in agriculture, biofertilisers are gaining attention nowadays due to their ability in targeting specific plant pathogens and at the same time provides a symbiosis relationship with the plants. Most importantly, they are biodegradable which also happens to be a key function in a sustainable agriculture (Bhardwaj et al., 2014). The balanced nutrients and beneficial microorganisms supply provided by biofertilisers keeps the crops healthy with higher yield. Thus, by enhancing the soil with biofertilisers, it would provide a great advantage towards the plant and the ecosystem on the whole.

Root growth is improved due to better soil structure and increased organic matter in the soils, thereby improves the nutrients exchange capacity, provides better water retention in soil, prevents soil acidity by buffering the soil, and lowers leaching loss of $\mathrm{N}$ and $\mathrm{P}$ through fixation. Biofertilisers have also been reported to suppress certain plant diseases, soil-borne diseases and parasites due to their biological control ability (Bender et al., 2016; Mishra and Dash, 2014; Nelson and Craft, 1992). Unlike chemical fertilisers, biofertilisers have none or little GHG emission, thus mitigating global warming and climate change. There are several types of beneficial microbes in a biofertiliser, which play different roles in helping for rejuvenation of the soil health. This will be explained later in the review.

\section{Microorganism-based Biofertilisers}

Biofertilisers consist of specialised bacteria, actinomycetes and fungi that contribute significantly in the nutrient manipulation of soil and imperative in improving the diversity of the rhizosphere in the oil palm plantation (Bhardwaj et al., 2014; Mishra and Dash, 2014). Typically, they are introduced into the soil by seed or soil inoculation. The preferred seed inoculation will be the seed coating while soil inoculation involves direct application into the soil via broadcasting, mulching, pocket application and various other suitable applications. The specific bacteria, actinomycetes and fungi multiply and participate in nutrient cycling which will benefit crop productivity when they are applied as soil inoculants or seeds (Bhardwaj et al., 2014). They contribute by keeping the soil environment rich in variety of micro- and macro-nutrients and $\mathrm{N}$ fixation, release of plant growth regulating substances, producing antibiotics and anti-fungal compounds, phosphate and $\mathrm{K}$ solubilisations and finally, the biodegradation of organic matters in soil. A number of biofertilisers are currently available in the market and briefly will be introduced and discussed in this article focusing on the positive impact on oil palm cultivation.

\section{Plant Growth-promoting Rhizobacteria (PGPR)}

PGPR represent a wide range of soil bacteria and they are well-known for their capability of plant growth promoting effect in stressed environment (Bhardwajet al., 2014). They are able to affect the plant growth directly and indirectly. Firstly, by facilitating the uptakes of nutrients from environments and supplying nutrients, which includes acquisition of $\mathrm{N}$ and $\mathrm{P}$ to the plants by the PGPR for plant growth, is known as direct promotion. Secondly, will be the indirect promotion of plant growth occurring during prevention of deleterious effect by pathogenic organisms, whereby they produce antagonistic metabolites or induce resistance towards pathogens (Glick, 1995; Vimal et al., 2017). Therefore, a general screening of these bacteria found them to be inhibitory to a wide range of pathogens (Kloepper and Schroth, 1981; Beneduzi et al., 2012; Sundram et al., 2015), where they act antagonistically towards plant pathogens by producing anti-microbials or by interfering with virulence factors (Turner et al., 2013). Some researchers have also reported that PGPR often have multiple modes of actions (Ratti et al., 2001).

The application of PGPR including Azospirillum, Bacillus and Pseudomonas spp. also favours the uptake of $\mathrm{N}$ and $\mathrm{P}$ by oil palm (Amir et al., 2005; Sundram et al., 2015) which allows them to facilitate on the plant growth. Interaction between PGPR with mycorrhiza was reported to promote oil palm health by suppression of plant pathogens under stressed environments (Sundram et al., 2015).

\section{Nitrogen Fixers}

Rhizobia. Major source of the $\mathrm{N}$ input in the agriculture soils are mainly by biological $\mathrm{N}$ fixation. The $\mathrm{N}$ fixing system plays a significant role in 
fertility improvement and productivity of low $\mathrm{N}$ soils (Zahran, 1999). Rhizobia have received major attention as an $\mathrm{N}$ fixers as well as symbiotic relationship with legumes. This group of bacteria is perhaps one of the oldest known soil symbiotic relationship with leguminous cover crop (LCC) that reduces atmospheric $\mathrm{N}_{2}$ in plant root nodules into ammonium to be used by host plants, while the plants supply essential minerals to the bacteria (Mishra and Dash, 2014). LCC are well-known in the oil palm plantation for $\mathrm{N}$ fixation by the $\mathrm{N}$ fixer bacteria and they provide the $\mathrm{N}$ source to oil palm. At the same time, they also minimise the losses of soil and nutrient during immature phase of oil palm planting, and improves fertility of the top soil by enhancing nutrient retention capacities, microbial activity and aeration (Teo et al., 2010).

Azotobacters and Azospirillum. These genera are free-living bacteria that fix atmospheric $\mathrm{N}_{2}$ in cereal crops without any symbiosis as they do not require a specific host plant. They play an important role in $\mathrm{N}$ cycle and possess a variety of metabolic functions such as producing anti-fungal compounds that suppresses many plant pathogens (Mishra and Dash, 2014). Azotobacters also has the ability in producing vitamins (thiamine and riboflavin) (Revillas et al., 2000) and some of the plant hormones indole acetic acid (IAA), cytokinins (CK) and also gibberellins (GA) (Abd El-Fattah et al., 2013). Study shows that by incorporating Azotobacter, they are able to enhance the seed germination and advancing root architecture while improving the plant growth (Gholami et al., 2009). As a result, Azospirillum is also a fantastic free-living aerobic bacterium that enhances plant growth and development. Om et al. (2009) showed that Azospirillum inoculated roots were denser and enhanced root hair formation compared to the noninoculated plants. The morphological changes on the root allows the plant to have greater absorption of nutrients from the environment, and this is due to the ability of Azospirillum in secreting plant growth regulating substances (Thuler et al., 2003).

\section{Phosphate-solubilising Microorganism (PSM)}

The $\mathrm{P}$ is the second essential macronutrient to plant after $\mathrm{N}$, where it largely associates with protein synthesis and plays a major role in biological development of plants. There are large amounts of insoluble P (95\%-99\%) fixed in the soil which makes them unavailable to be utilised by plants (Perez Corona et al., 1996). Increasingly, insolubility of $\mathrm{P}$ in soil is due to its high stability as it rapidly reacts with other compounds such as $\mathrm{Al}^{3+}, \mathrm{Ca}^{2+}$ and $\mathrm{Fe}^{3+}$ (Pande et al., 2017). Usage of PSM is an advantageous alternative way to enhance $P$ availability in sustainable agricultural practices.
Phosphobacterins, mainly constituting of bacteria (Bacillus spp., Pseudomonas spp. and Rhizobium spp.) and fungi (Aspergillus spp.), allow insoluble $\mathrm{P}$ to become available to plants through a solubilisation effect (Bhardwaj et al., 2014; Mishra and Dash, 2014). Many workers have reported on the important role of phosphate-solubilising bacteria (PSB) as biofertilisers in the oil palm cultivation for promoting plant growth and their use as a sustainable approach (Acevedo et al., 2014; Situmorang et al., 2015). In spite of the positive attributes of PSM, it is yet to gain the confidence to replace or be applied in combination with chemical fertilisers in the pursuit of sustainable agriculture.

\section{Zinc Solubilising Microorganisms}

The $\mathrm{Zn}$ deficiency retards photosynthesis and $\mathrm{N}$ metabolism in plants, causes reduction in fruit development, reduces synthesis of carbohydrate and phytohormones, and also affects the crop maturity which subsequently decreases crop yield and quality (Hafeez et al., 2013). Zn fertilisers tend to convert into unavailable form depending on the soil types and chemical reaction, and this can be reversed by applying microbial inoculants that are Zn solubilisers (Saravanan et al., 2007). Bacteria such as Pseudomonas, Pantoea, Bacillus, Azospirillum and Rhizobium were reported having the ability in $\mathrm{Zn}$ solubilising and significantly improved the growth development of the plants (Kamran et al., 2017). Therefore, this leads to the importance of $\mathrm{Zn}$ solubilising bacteria to convert $\mathrm{Zn}$ into soluble form to oil palm for nutrient uptake. Study has been reported on the disease occurrence where higher amount of $\mathrm{Zn}$ in oil palm had higher resistance towards the attack of Ganoderma (Rakib et al., 2017).

\section{Biological Control Agent (BCA) and Plant Growth Promoter (PGP)}

Both BCA and PGP have gained popularity in sustainable agriculture over the past two decades with the increasing awareness in pests and diseases (P\&D) control using chemicals. These beneficial microbes not only possess control mechanism on the pathogens of interest but also contribute positively on the plant-soil interaction. The beneficial microbes, if exploited correctly, are able to contribute significantly as a component in the rejuvenation of soil. Among them, microbes such as Trichoderma (Angel et al., 2016; Sundram, 2013) and arbuscular mycorrhiza (AM) (Sundram et al., 2015) fungi have been well received by the industry. Microbes with beneficial effect on the crop have an added advantage as they also increase the diversity of soil microorganisms through their interaction and colonisation in soil. 
Trichoderma. Trichoderma spp. is an opportunistic fungus that resides primarily in soil or in plant tissues. They are found in many root ecosystems and it has been observed that plant-derived sucrose plays an important role in facilitating root colonisation by Trichoderma cells and coordinating defence mechanisms (Vargas et al., 2008). Species of Trichoderma are widely recognised as BCA due to their ability in producing antibiotics, mycoparasitism, competition for nutrients and production of cell wall-degrading enzymes in defence against different kinds of plant pathogens (Harman et al., 2004; Shakeri and Foster, 2007; Sundram, 2013; Angel et al., 2016). Additionally, certain species of Trichoderma also employs other beneficial effects towards plant such as promoting growth development and nutrient uptake, fertiliser use efficiency and tolerance to abiotic stresses (Lorito et al., 2010). Utilising natural source to develop antagonistic activity against harmful plant pathogens and plant growth development is recommended in sustainable agriculture to reduce the usage of chemical pesticides that are harmful to the environment (Sadoma et al., 2011).

Trichoderma has been extensively studied for its role to protect oil palm against infection caused by G. boninense (Sundram et al., 2008; Sundram, 2013). The ability of Trichoderma in secreting antifungal metabolites has been reported where they caused physical deformation on the hyphae of $G$. boninense during interaction (Siddiquee et al., 2009; Angel et al., 2016; 2018). Furthermore, the nursery and field assessment conducted by Sundram et al. (2016) showed the potential of isolated endophytic Trichoderma strains as suitable biofertilisers for the management of disease in the oil palm cultivation. Taking into consideration of their multiple beneficial effects on the oil palm, they can be effectively used for the management of soil health in a sustainable way.

Arbuscular mycorrhiza (AM) fungi. Taxonomically, AM fungi are characterised under the phylum Zygomycota which encompasses a total of six genera belonging to Acaulospora, Glomus, Gigaspora, Sclerocystis, Entrophospora and Scutellospora. Similar to Trichoderma, AM fungi is a beneficial interaction in modern sustainable agriculture as they are able to reduce damage caused by plant pathogens, promote plant growth, cost-effective and environmentalfriendly (Sundram et al., 2015; Dar and Reshi, 2017). Study shows that host tolerance to pathogen attack has been increased after the inoculation of AM by lowering the disease development in plants (Sundram et al., 2015). Furthermore, AM is a symbiont that forms a mutually beneficial relationship between the fungi and plant roots whereby the fungi supply $\mathrm{P}$ in exchange for $\mathrm{C}$ from the host (Bhardwajet al., 2014; Lemanceau et al., 2017). The fungi have special structures such as arbuscular and vesicles for enhanced nutrient uptake (Jeffries et al., 2003). The fungus is also capable of extending its mycelial network up to 100-fold higher compared to the normal plant roots network (Smith and Read, 2008).

A study by Sundram (2010) has demonstrated that species of AM, Glomus intraradices and G. clarum had increased the vegetative growth of oil palms significantly and this could be achieved without the addition of inorganic fertilisers. Sundram et al. $(2011 ; 2015)$ also showed the ability of AM as a BCA against $G$. boninense, a white rot fungal pathogen that causes serious disease to the oil palm (Idris, 1999).

Hendersonia, actinomycetes, basidiomycetes, hymenomycetes. Apart from the described Trichoderma and AM fungi, other beneficial microbes were also subjected as BCA and plant growth promoter. Among them is Hendersonia sp. was identified as potential BCA against G. boninense infection based on in vitro study and nursery trials (Nurrashyeda et al., 2018). Subsequently, endophytic Hendersonia was developed into a biofertiliser GanoEF, serving as microbial inoculants, organic and inorganic fertiliser (Idris et al., 2012). This biofertiliser is beneficial which applied in oil palm plantation due to its potential in improving oil palm resistance against Ganoderma infection and at the same time rejuvenating the soil ecosystem.

Actinomycetes on the other hand, are a group of microorganisms that are distributed widely in natural ecosystems. Their role in promoting plant growth and plant defence has been well studied and recognised around the world. In vitro and nursery trials was conducted by ShariffahMuzaimah et al. $(2015 ; 2018)$ proving the potentials of Streptomycetes-like actinomycetes as BCA against G. boninense in oil palm. Besides these microbes, a recent investigation on white-rot hymenomycetes as biodegraders was conducted by Naidu et al. (2018). The white-rot hymenomycetes produce enzymes such as hydrolytic and oxidative lignolytic enzymes whereby the former is capable of degrading wood polysaccharides while the latter degrades lignin. These findings will benefit in the biological management strategy in oil palm plantation by minimising the spread of disease inoculum in a sustainable manner.

Although there are many benefits contributed by biofertilisers as mentioned earlier, there are some concerns over their usage in the crop cultivation. It is also noteworthy to mention that despite the increasing literature on biofertilisers, research is still lacking on the microbial understanding especially on the functional diversity, colonising ability, mode of actions and judicious applications to recommend their use as a reliable component in sustainable agriculture. The other issue that is of concern 
for every farmer is the high cost of biofertilisers compared to chemical fertilisers. One of the major issues pertaining to biofertilisers is the fact that they have a short shelf-life, vulnerable towards high temperatures and issues relating to their storage. Another common factor discouraging planters into venturing on biofertilisers would be the collecting, transporting and management of inputs and most importantly, economic returns of investments. Taking into consideration of all the above, the advantages of these fertilisers need to be integrated in order to optimise the usage and achieve balanced nutrient management for crop growth which will be deliberated in the next section.

\section{INTEGRATING SOIL HEALTH AND MANAGEMENT STRATEGIES}

Global demand for vegetable oil is expected to approach 240 million tonnes and anticipated to be doubled in 2050 owing to the expanding world population (Corley, 2009), and palm oil is expected to contribute the most for the additional requirements. A yield target of $5.2 \mathrm{t}$ palm oil ha- $\mathrm{h}^{-1}$ $\mathrm{yr}^{-1}$ was suggested by Corley (2009) should be met to considerably reduce the development of new production area in order to satisfy future demand. However, agricultural productivity has been in structural decline globally, added with the effect from climate change and extreme weather which further decreases the yield gains. As proposed, productivity can be increased by $10 \%-15 \%$ with the improvement in soil health contributing to a potential productivity increase of up to $60 \%$ with the combination of efficient crop varieties (Singh, 2017).

Sustainable crop production highly encourages natural and greener approaches in agriculture, such as integrated fertiliser application. It is characterised that by the combined applications of chemical, organic and biofertilisers trigger different dynamics of nutrient availability compared to those of chemical fertiliser application alone. Combined uses of these fertilisers are able to decrease damage due to over application of chemical fertilisers, which in return may improve crop productivity. On the other hand, studies have reported that combined fertiliser application increases the microbial biomass, hence, improving soil health where the application of organic fertilisers can further enhance the biodiversity provided by biofertilisers alone (Dutta et al., 2003; Bokhtiar and Sakurai, 2005; Chen, 2006). It was also reported that SOM was also positively increased due to the fertiliser application.

One of the most important components in Integrated Farming Systems (IFS) is the Integrated Soil Fertility Management (ISFM). IFS basically contains various aspects of nutrient management while ISFM is a set of soil fertility management practices that requires the usage of fertiliser and organic inputs supplemented with enhanced germplasm. The combination of these two systems with the collective knowledge on the adaption of these practices to local conditions can be achieved. In overcoming the improvement of crop productivity, these practices are aimed at maximising agronomic use efficiency of the applied nutrients.

A complementing component to the ISFM would be the Integrated Plant Nutrient Management (IPNM)/Integrated Nutrient Management (INM) (Reetz, 2016; Singh and Ryan, 2015). The system aims for the balanced use of nutrients from chemical, organic and biofertilisers in a more efficient manner. The concept of IPNM/INM is not new for the oil palm industry with its conception dating back in the early 1980s. It basically suggests that the healthy growth and optimum economics of FFB yields is through supplying adequate nutrients to the palms, maintaining soil fertility and health for sustained crop productivity on a long-term basis. It further emphasises on the application of the fertilisers in the plantation areas where the nutrient uptake is the most efficient, and also minimising the negative environmental impacts (Reetz, 2016). In a recent review by Biramo (2018), INM approach in the pursuit of improving crop yield and enhancing soil fertility found appropriate positive response on soil properties. The INM programme was successfully conducted under the smallholder farmers in subSaharan Africa focussing on Ethiopia. In overcoming the issues concerning crop productivity and soil fertility, the two decades of investigation addressed some of the crucial factors in the component of soil fertility especially on the decrease in the organic matter and nutrient content of the soil. In one of the sub-Saharan studies located in Eastern Ethiopia, the workers reported an abrupt drop in crop productivity and soil fertility. Interestingly, after a four-year study by Haramaya University, they found that combination of mineral fertilisers and farm yard manure (FYM) gave the best productivity improvement for maize. It was indicated that application of $10 \mathrm{t} \mathrm{ha}^{-1}$ FYM alone can give equal yield as 100 and $100 \mathrm{~kg}^{-1} \mathrm{NP} \mathrm{ha}^{-1}$ together.

A comprehensive write-up on the components of IPNM/INM in oil palm has been critically discussed by Goh et al. (2011). The authors highlight the integration of microbial, organic and specialty (chemical) fertilisers in oil palm plantations. Interestingly, over the years, the attention on biofertilisers has taken the lead owing to the global concern on sustainability. Owing to the increasing awareness on soil health and sustainability in agriculture, components such as organic manures, diverse organic materials, biofertilisers, animal manures, green manures, crop residues, sewage sludge and food industry wastes have gained the deserved attention in the IPNM / INM system (Singh 
and Ryan, 2015). The combination of different organic sources and fertiliser nutrients in the form of supplement is recommended for the possible improvement in soil fertility and health which will in return sustains crop productivity in the long run. These technologies were introduced to the local stakeholders in agro-industry in promoting soil health while allowing the farmers to understand the importance in maintaining soil health for future.

Utilisation of chemical fertilisers is an efficient way to improve the fertility of the rhizospheres as the nutrients are soluble and directly available to plants. Due to the impact on environmental quality by continuous usage of chemical fertilisers, combined use of chemical and organic fertiliser to mitigate the deficiency of micronutrients in the plantation has proven to be beneficial. Good agronomic practices include recycling of oil palm biomass such as the EFB into composts and eventually returning to the palms as organic fertiliser is being actively investigated. This is an on-going effort to reduce the dependency on chemical fertiliser as well as moving into healthier food production with programmes encouraging recycling and use of agriculture wastes as organic fertilisers are being explored. Another similar study on the use of organic fertiliser concluded that poor irrigation in plots treated with organic fertilisers affects the yield as compared to plots that are adjacent to water supply (Syura and Tsan, 2008). In recent years, liquefaction has gained its popularity due to its simplicity, transforming the waste product into value-added products (Awalludin et al., 2015).

Constant fertiliser application improves the fertility of the soil. However, high intensity of land use and high dependence on chemical application eventually have adverse effect on the soil biodiversity. It is important to enhance and maintain the diversity of the soil for a proper functioning of ecosystems (Bender et al., 2016). To compromise this, biofertiliser has the potential for ecological intensification as sustainable approach. Additionally, application of organic fertilisers also enhances biodiversity of microorganisms because they act as a source of nutrients for the inhabitation of the microorganisms. Therefore, both organic and biofertilisers work well together in rejuvenating soil health. Figure 1 illustrates the overall roles of plant beneficial microorganisms in helping the oil palm cultivation to achieve sustainable agriculture.

With the current advancement in technology, global positioning system (GPS), geographic information systems (GIS), electronic sensors and controllers gave rise to precision farming. Thus, providing new opportunities in crop improvement and management of soil on a site-specific basis, known as site-specific nutrient management

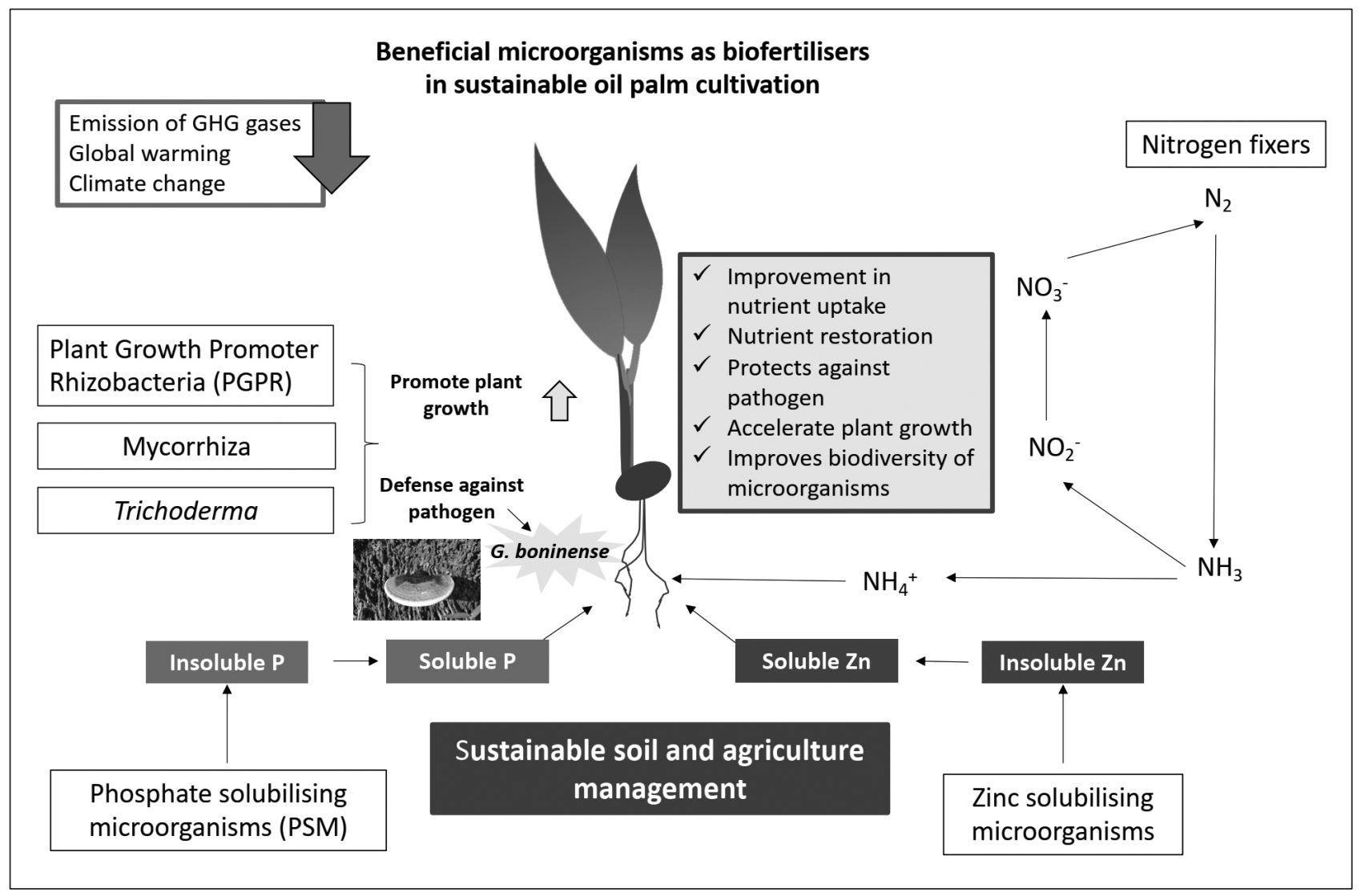

Figure 1. Potential usage of soil microbes as a biofertiliser for sustainable oil palm cultivation. 
(SSNM). This application of SSNM ensures that nutrients are applied according to the needs of the soil-plant system with fertilisers, whether based on nutrient status of soil or plant in each field. A balanced and well-reviewed fertiliser application recommendation is required for oil palm. Farmers are now able to tailor-made the nutrient management according to the specific conditions of their plantation, providing a framework for best management practices and soil health is maintained on a long-term basis which is determined from anticipated yield gain, application of fertilisers and their targeted efficiency (Singh and Ryan, 2015).

SSNM incorporated with nutrient balances are suggested to assist in identifying the situation particularly on over application of fertilisers which might end up with high production cost or excessive losses to the environment. In order to maximise the profit, it is important for an extensive planning on nutrient management conducted on components that complement with each other. These components were highlighted by Tarmizi and Mohd Tayeb (2006). It is an uphill challenge for the oil palm industry where research will be difficult but not impossible.

For an improved fertiliser management and its efficiency, it is crucial to acquire knowledge on the soil properties; $\mathrm{pH}$, acidity, $\mathrm{SOM}$, moisture and other relevant characteristics of the soil. The growers must also be educated to manage their plantation soils in order to conserve the valuable plant nutrients and minimise losses of crop yields (Tarmizi and Mohd Tayeb, 2006). Fertiliser management in oil palm has always emphasised on minimising nutrient losses. Oil palm in the early years was predominantly cultivated on mineral soil, subsequently expanding to marginal soils such as peat and in soils on hilly terrain. This led to the serious problems of fertiliser leaching, soil erosion and surface runoff (Goh et al., 2011; Veloo et al., 2015). Therefore, minimising nutrient losses through soil processes requires serious investigation as this would be one of the major linkages to the nutrient loss for the improvement of fertiliser use efficiency.

Farmers adopt appropriate management practices, such as split application (Reetz, 2016) according to crop requirements. Besides this, breeding programme that addresses selection of oil palm genotypes that are able to produce good yields on low fertiliser inputs while providing consistent leaf nutrition needs to be given consideration. The industry needs to realise that balancing the fertiliser application through IPNM/INM with chemical, organic and biofertiliser will provide a healthy soil for a sustainable agriculture system for oil palm without compromising the potential yield of the crop.

Implementation and development of fertiliser management practices has evolved and often guided by scientific principles (Singh and Ryan, 2015). NUE is a concept to assess the performance of nutrient management in crop production systems (Oberthür and Donough, 2017). The goal of NUE is to increase the overall performance of the cropping system by matching crop as accurately as possible to the nutrient needs, while minimising environmental impacts. This concept is projected by nutrient stewardship, which has similar goal to NUE essentially describes the selection of the right source of nutrients for application at the right rate, at the right time and in the right place (Reetz, 2016; Singh and Ryan, 2015) or '4R Nutrient Stewardship'. The concept basically is to achieve social, economic and environmental benefits with the efficient use of plant nutrients. Adequate supply of nutrients further contributes to plant growth and eventually increases the yield gain.

As discussed previously, fertilisers can affect the soil health in a positive or negative manner. Therefore, adoption of good science-based nutrient management practices for soil is important to ensure the production of economic crop with reducing environmental effects (Singh and Ryan, 2015). Studies have indicated that reducing organic and chemical fertilisers combined with the inoculation of beneficial microbes (biofertilisers) is a better alternative in lessening $\mathrm{P}$ accumulation in the soil, while saving costs by reducing chemical and organic fertiliser inputs. Developing a suitable IPNM/INM will be a challenge to reach the goal of sustainable agriculture; however, research is a MUST. Much effort had been invested by researchers on studying the importance of microbial-based fertilisers are able to oil palm cultivation over the past decade. These results may assist in enhancing soil biodiversity complemented with the use of chemical fertilisers. The usage of organic and biofertilisers are able to compensate and balance out the shortcomings caused by chemical fertilisers, thus regaining soil health and being sustainable at the same time.

\section{CONCLUSION AND FUTURE PERSPECTIVES}

Globally, the interest in evaluating quality and health of our soil resources has been triggered by the increasing awareness that soil is an important component of earth's biosphere, especially in its ability to function as a sustainable component in agriculture. Although the definition of soil health is still vague and evolving, we need to realise that future agronomic research will need to incorporate soil health as one of the most important criteria to be considered in research on fertiliser use in crop production. Fertiliser management is a pivotal component in the productivity and profitability of oil palm. The industry needs to incorporate the different components of ISFM to collectively 
maximise the interactions resulting from the fortified combination of fertilisers coupled with advanced breeding materials and agronomic knowledge. The complete realisation of ISFM does not only focus on the nutrient sources, but also other complex interaction factors such as weed and insect control, different crop varieties, adaptation to local environment, agronomic practices and seasonal weather conditions. Complicated research addressing nutrient cycling, dynamics, soil biodiversity and ecosystem will further improve fertiliser use in oil palm for the development of new soil fertility management approaches.

Constant removal of nutrients by the oil palm, soil leaching and other factors that affects soil health over the years suggest that soil needs to be rejuvenated by using appropriate formulation between the chemical, organic and biofertilisers. However, this is an uphill challenge for the oil palm industry that requires long-term tedious assessments in order to reap the benefits of the combined application. This will require serious collaborative synergies by local research organisations by combining their technical expertise and planters' knowledge to address common problems and possibly to conduct meta analyses of experimental data collected over the years. The MPOB should be spearheading this national research effort. It is highly recommended to form a national soil rejuvenation committee comprising of local research institutions and universities to better understand these complex interactions in soil health. The committee should be represented by agronomist, microbiologist, breeders, plant physiologist and statisticians to strategise the way forward in soil health research. Most importantly, the objective of this committee would be to unite the past, existing, new and ongoing field fertiliser data for another comprehensive analysis and to identify loopholes or weaknesses for future fertiliser use efficiency investigation.

Without doubt, soil fertility issue ultimately precedes as one of the most important components of sustainable oil palm cultivation. It is a communal responsibility to ensure that appropriate rejuvenation programmes are implemented to safeguard the future of the industry.

\section{ACKNOWLEDGEMENT}

The authors would like to thank the Director-General of MPOB for permission to publish this article.

\section{REFERENCES}

Abd El-Fattah, D; Eweda, W E; Zayed, M S and Hassanein, M K (2013). Effect of carrier materials, sterilization method, and storage temperature on survival and biological activities of Azotobacter chroococcum inoculant. Annals of Agricultural Sciences, 58: 111-118.

Abu Bakar, R; Darus, S Z; Kulaseharan, S and Jamaluddin, N (2011). Effects of ten-year application of empty fruit bunches in an oil palm plantation on soil chemical properties. Nutrient Cycling in Agroecosystems, 89: 341-349.

Acevedo, E; Galindo-Castaneda, T; Prada, F; Navia, $\mathrm{M}$ and Romero, H M (2014). Phosphate-solubilizing microorganisms associated with the rhizosphere of oil palm (Elaeis guineensis Jacq.) in Colombia. Applied Soil Ecology, 80: 26-33.

Afandi, A M; Zuraidah, Y; Nurzuhaili, H A Z A; Zulkifli, H and Yaqin, M (2017). Managing soil deterioration and erosion under oil palm. Oil Palm Bulletin No. 75: 1-10.

Amir, H G; Shamsuddin, Z H; Halimi, M S; Marziah, $\mathrm{M}$ and Ramlan, M F (2005). Enhancement in nutrient accumulation and growth of oil palm seedlings caused by PGPR under field nursery conditions. Communications in Soil Science and Plant Analysis, 36: 15-16.

Angel, L P L; Sundram, S; Tay, B Y P; Yusof, M T and Ismail, I S (2018). Profiling of anti-fungal activity of Trichoderma virens 159c involved in biocontrol assay of Ganoderma boninense. J. Oil Palm Res. Vol. 30(1): 83-93.

Angel, L P L; Yusof, M T; Ismail, I S; Tay, B Y P; Mohamed Azni, I N A; Kamarudin, N H and Sundram, S (2016). An in vitro study of the antifungal activity of Trichoderma virens $7 \mathrm{~b}$ and a profile of its non-polar antifungal components released against Ganoderma boninense. J. Microbiology, 54: 732-744.

Awalludin, M F; Sulaiman, O; Hashim, R and Wan Nadhari, W N A (2015). An overview of the oil palm industry in Malaysia and its waste utilization through thermochemical conversion, specifically via liquefaction. Renewable and Sustainable Energy Reviews, 50: 1469-1484.

Azwan, MB; Norasikin, A L; Abd Rahim, S; Norman, $\mathrm{K}$ and Salmah, J (2016). Analysis of energy utilisation in Malaysian oil palm mechanisation operation. J. Oil Palm Res. Vol. 28(3): 485-495.

Bender, S F; Wagg, C and Van Der Heijden, M G A (2016). An underground revolution: Biodiversity and soil ecological engineering for agricultural sustainability. Trends in Ecology \& Evolution, 31(6): 440-452. DOI: http://dx.doi.org/10.1016/j. tree.2016.02.016. 
Beneduzi, A; Ambrosini, A and Passaglia, L M P (2012). Plant growth-promoting rhizobacteria (PGPR): Their potential as antagonists and biocontrol agents. Genetics and Molecular Biology, 35: 1044-1051.

Bhardwaj, D; Ansari, M W; Sahoo, R K and Tuteja, N (2014). Biofertilizers function as key player in sustainable agriculture by improving soil fertility, plant tolerance and crop productivity. Microbial Cell Factories, 13: 66.

Biramo, G (2018). The role of integrated nutrient management system for improving crop yield and enhancing soil fertility under smallholder farmers in sub-Saharan Africa: A review article. Modern Concepts \& Developments in Agronomy, 2(5): 1-9.

Bokhtiar, S M and Sakurai, K (2005). Effects of organic manure and chemical fertilizers on soil fertility and productivity of plant and ratoon crops of sugarcane. Archives of Agronomy and Soil Science, 51: 325-334.

Broeshart, H; Ferwerda, J J D and Kovachich, W G (1957). Mineral deficiency symptoms of the oil palm. Plant Soil, 8: 289-300.

Chand, S; Anwar, M and Patra, D D (2006). Influence of a long-term application and inorganic fertilizer to build up soil fertility and nutrient uptake in mintmustard cropping sequence. Communications in Soils Science and Plant Analysis, 37: 63-76.

Chen, J H (2006). The combined use of chemical and organic fertilizer and/or biofertilizer for crop growth and soil fertility. Proc. of the International Workshop on Sustained Management of the Soil Rhizosphere System for Efficient Crop Production and Fertilizer Use. Bangkok, Thailand. p. 1-11.

Corley, R H V (2009). How much palm oil do we need? Environmental Science and Policy, 12: 134-139.

Dar, M H and Reshi, Z A (2017). Vesicular arbuscular mycorrhizal (VAM) fungi as a major biocontrol agent in modern sustainable agriculture system. Russian Agricultural Sciences, 43: 138-143.

Doran, J W and Zeiss, M R (2000). Soil health and sustainability: Managing the biotic component of soil quality. Applied Soil Ecology, 15: 3-11.

Dutta, S; Pal, R and Chakeraborty, A (2003). Influence of integrated plant nutrient supply system on soil quality restoration in a red and laterite soil. Archives of Agronomy and Soil Science, 49: 631-637.

Gholami, A; Shahsavani, S and Nezarat, S (2009). The effect of plant growth promoting rhizobacteria
(PGPR) on germination, seedling growth and yield of maize. International Scholarly and Scientific Research and Innovation, 3: 2009.

Glick, B R (1995). The enhancement of plant growth by free-living bacteria. Canadian J. Microbiology, 41: 109-117.

Goh, K J and Härdter, R (2003). General oil palm nutrition. Oil Palm: Management for Large and Sustainable Yields (Fairhurst, T H and Härdter, R eds.). PPI, Switzerland. p. 191-230.

Goh, K J; Ng, P H C; Mahamooth, T N; Petronella, G A T and Gan, H H (2011). Integrated oil palm nutrient management and its implication on environmental quality. Proc. of the PIPOC 2011 International Palm Oil Congress: Palm Oil: Fortifying and Energizing the World - Agriculture Conference. MPOB, Bangi. p. 441-454.

Guillaume, T; Holtkamp, A M; Damris, M; Brummer, B and Kuzyakov, Y (2016). Soil degradation in oil palm and rubber plantations under land resource scarcity. Agriculture, Ecosystems and Environment, 232: 110-118.

Hafeez, B; Khanif, Y M and Saleem, M (2013). Role of zinc in plant nutrition - A review. American J. Experimental Agriculture, 3: 374-391.

Han, S H; An, J Y; Hwang, J; Kim, S B and Park, B B (2015). The effects of organic manure and chemical fertilizers on the growth and nutrient concentrations of yellow poplar (Liriodendron tulupifera Lin.) in a nursery system. Forest Science and Technology, 12: 137-143.

Harman, G E; Howell, C R; Viterbo, A; Chet, I and Lorito, M (2004). Trichoderma species Opportunistic, avirulent plant symbionts. Nature Reviews Microbiology, 2(1): 43-56.

Idris, A S (1999). Basal Stem Rot (BSR) of Oil Palm (Elaeis guineensis Jacq.) in Malaysia: Factors Associated with Variation in Disease Severity. Ph.D thesis, Wye College, The University of London, UK.

Idris, A S; Mohd Shukri, I; Norman, K; Choo, Y M; Kushairi, A; Hanafi, M M; Mohd Nawawi, W and Zaafar, M D (2015). Chemical fertiliser GanoCare as preventive treatment in controlling Ganoderma disease of oil palm. MPOB Information Series No. 564: $4 \mathrm{pp}$.

Idris, A S; Mohd Shukri, I; Norman, K; Kushairi, A; Choo, Y M; Hanafi, M M; Talib, R and Sodian, M Y M (2014). GanoCare-reducing risk of Ganoderma infection in oil palm. MPOB Information Series No. 545: 4 pp. 
Idris, A S; Nurrashyeda, R; Maizatul, S M; Madihah, A Z; Tarmizi, A M; Kushairi, A; Wan Azha, W M and Tony Peng, S H (2012). Biofertiliser Hendersonia GanoEF as biological control of Ganoderma in oil palm. MPOB Information Series No. 508: 4 pp.

Jeffries, P; Gianinazzi, S; Perotto, S; Turnau, K A and Barea, J-M (2003). The contribution of arbuscular mycorrhizal fungi in sustainable maintenance of plant health and soil fertility. Biol. Fertil. Soils, 37: $1-16$.

Kamran, S; Shahid, I; Baig, D N; Rizwan, M; Mailk, K A and Mehnaz, S (2017). Contribution of zinc solubilizing bacteria in growth promotion and zinc content of wheat. Frontiers in Microbiology, 8: 2593.

Khasanah, N; Noordwijk, M V; Ningsih, H and Rahayu, S (2015). Carbon neutral? No change in mineral soil carbon stock under oil palm plantations derived from forest or non-forest in Indonesia. Agriculture, Ecosystems and Environment, 211: 195206.

Kibblewhite, M G; Ritz, K and Swift, M J (2008). Soil health in agricultural systems. Philosophical Transactions of the Royal Society B: Biological Sciences, 363: 685-701.

Kloepper, J W and Schroth, M N (1981). Relationship of in vitro antibiosis of plant growth promoting rhizobacteria to plant growth and displacement of root microflora. Phytopathology, 71(10): 1020-1024.

Kushairi, A; Meilina, O A; Balu, N; Elina, H; Mohd Noor Izuddin, Z B; Razmah, G; Vijaya, S; Sundram, S and Ahmad Parveez, G K (2019). Oil palm economic performance in Malaysia and R\&D progress in 2018. J. Oil Palm Res. Vol. 31(2): 165-194. DOI: https: / / doi. org/10.21894/jopr.2019.0026.

Lal, R (2015). Restoring soil quality to mitigate soil degradation. Sustainability, 7: 5875-5895.

Lemanceau, P; Barret, M; Mazurier, S; Mondy, S; Pivato, B; Fort, T and Vacher, C (2017). Plant communication with associated microbiota in the spermosphere, rhizosphere and phyllosphere. How Plants Communicate with their Biotic Environment (Becard, G ed.). p. 101-133.

Lim, K C and Zaharah, A R (2002). The effect of oil palm empty fruit bunches on oil palm nutrition and yields and soil chemical properties. J. Oil Palm Res. Vol. 14(2): 1-9.

Lobell, D B (2007). The cost of uncertainty for nitrogen fertilizer management: A sensitivity analysis. Field Crops Research, 100: 210-217.
Lord, S and Clay, L (1999). Environmental Impacts of Oil Palm - Practical Considerations in Defining Sustainability for Impacts on the Air, Land and Water. New Britain Palm Oil LTD Centre, Dami Oil Palm Research Station. 38 pp.

Lorito, M; Woo, S L; Harman, G E and Monte, E (2010). Translational research on Trichoderma: From omics to the field. Annual Review Phytopathology, 48: 395-417.

McCauley, A (2009). Plant nutrient functions and deficiency and toxicity symptoms. Extension service continuing education series. Nutrient Management. Module No. 9. Montana State University. p. 1-15.

Mishra, P and Dash, D (2014). Rejuvenation of biofertilizer for sustainable agriculture and economic development. Consilience: The J. Sustainable Development, 11(1): 41-61.

Mole, B (2014). Fertilizer produces far more greenhouse gas than expected. ScienceNews: Magazine of the Society for Science and the Public. https: / / www.sciencenews.org / article / fertilizerproduces-far-more-greenhouse-gas-expected, accessed on 2 July 2019.

Naidu, Y; Siddiqui, Y; Rafii, M Y; Saud, H M and Idris, A S (2018). Investigating the effect of whiterot hymenomycetes biodegradation on basal stem rot infected oil palm wood blocks: Biochemical and anatomical characterization. Industrial Crops and Products, 108: 872-882.

Neher, D A (2001). Role of nematodes in soil health and their use of indicators. J. Nematology, 33(4): 161-168.

Nelson, E B and Craft, C M (1992). Suppression of dollar spot on creeping bentgrass and annual bluegrass turf with compost-amended top dressings. Plant Disease, 76: 954-95.

Nurrashyeda, R; Idris, A S; Madihah, A Z; Maizatul, S M and Sebrane, N H (2018). Biocontrol of basal stem rot (BSR) disease of oil palm using endophytic fungus, Hendersonia sp. International J. Pure and Applied Mathematics, 118: 3-22.

Oberthür, T and Donough, C (2017). Nutrient use efficiency of oil palm in Malaysia and Indonesia. Proc. of the PIPOC 2017 International Palm Oil Congress: Treasuring the Past, Charting the Future Agriculture Conference. MPOB, Bangi. p. 18-20.

Om, A Z; Ghazali, A H A; Keng, C L and Ishak, Z (2009). Microbial inoculation improves growth of oil palm plants (Elaeis guineensis Jacq.). Tropical Life Science Research, 20: 71-77. 
Pande, A; Pandey, P; Mehra, S; Singh, M and Kaushik, S (2017). Phenotypic and genotypic characterization of phosphate solubilizing bacteria and their efficiency on the growth of maize. J. Genetic Engineering and Biotechnology, 15(2): 379-391.

Perez Corona, M E; Van Der Klundert, I and Verhoeven, J T A (1996). Availability of organic and inorganic phosphorus compounds as phosphorus sources for Carex species. New Phytologist, 133: 225-231.

Rakib, M R M; Bong, C F J; Khairulmazmi, A; Idris, A S; Jalloh, M B and Ahmed, O H (2017). Association of copper and zinc levels in oil palm (Elaeis guineensis) to the spatial distribution of Ganoderma species in the plantation on peat. J. Phytopathology, 165(4): 276282.

Ratti, N; Kumar, S; Verma, H N and Gautams, S P (2001). Improvement in bioavailability of tricalcium phosphate to Cymbopogo martini varmotia rhizobacteria. AMF and Azospirilium inoculation. Microbiology Research, 156: 145-149.

Reetz, H F J (2016). Fertilizers and their Efficient Use. International Fertilizer Industry Association (IFA). Paris, France.

Revillas, J J; Rodelas B; Pozo, C; Martinez-Toledo, M V and Gonzalez-Lopez, J (2000). Production of B-group vitamins by two Azotobacter strains with phenolic compounds as sole carbon source under diazotropic and adiazotrophic condition. J. Applied Microbiology, 89: 486-493.

Sadoma, M T; El-Sayed, A B B and El-Moghazy, S M (2011). Biological control of downy mildew disease of maize caused by Peronosclerospora sorghi using certain biocontrol agents alone or in combination. J. Agriculture Research Kafer El-Sheikh University, 37: 1-11.

Sahat, S; Yusop, Z; Askari, M and Ziegler, A D (2016). Estimation of soil erosion rates in oil palm plantation with different land cover. IOP Conf. Series: Materials Science and Engineering, 136: 012086. DOI:10.1088/1757-899X/136/1/012086, accessed on 6 September 2017.

Saravanan, V S; Madhaiyan, M and Thangaraju, M (2007). Solubilization of zinc compounds by the diazotrophic, plant growth promoting bacterium Gluconacetobacter diazotrophicus. Chemosphere, 66: 1794-1798.

Shakeri, J and Foster, H A (2007). Proteolytic activity and antibiotic production by Trichoderma harzianum in relation to pathogenicity to insects. Enzyme and Microbial Technology, 40(4): 961-968.
Shariffah-Muzaimah, S A; Idris, A S; Madihah, A Z, Dzolkhifli, O; Kamaruzzaman, $\mathrm{S}$ and Cheong, P C H (2015). Isolation of actinomycetes from rhizosphere of oil palm (Elaeis guineensis Jacq.) for antagonism against Ganoderma boninense. J. Oil Palm Res. Vol. 27(1): 19-29.

Shariffah-Muzaimah, S A; Idris A S; Madihah, A Z; Dzolkhifli, O; Kamaruzzaman, S and Maizatul, S M (2018). Characterization of Streptomycetes spp. isolated from the rhizosphere of oil palm and evaluation of their ability to suppress basal stem rot disease in oil palm seedlings when applied as powder formulation in a glasshouse trial. World J. Microbiology and Biotechnology, 34: 15.

Siddiquee, S; Yusuf, U K; Hossain, K and Jahan, S (2009). In vitro studies on the potential Trichoderma harzianum for antagonistic properties against Ganoderma boninense. J. Food, Agriculture and Environment, 7: 970-976.

Singer, M J and Munns, M D (2002). Soils - An Introduction to Soil. Upper Saddle River, USA. 429 pp.

Singh, B (2017). Integrating soil/crop health and management strategies to enhance farm productivity and sustainability. Proc. of the PIPOC 2017 International Palm Oil Congress: Treasuring the Past, Charting the Future - Agriculture Conference. MPOB, Bangi. p. 21-24.

Singh, B and Ryan, J (2015). Managing Fertilizers to Enhance Soil Health. International Fertilizer Industry Association (IFA). Paris, France. 24 pp.

Situmorang, E C; Prameswara, A; Sinthya, H C; Toruan-Mathius, N and Liwang, T (2015). Indigenous phosphate solubilizing bacteria from peat soil for an eco-friendly biofertilizer in oil palm plantation. KnE Energy, 1: 65-72.

Smith, S E and Read, D J (2008). Mycorrhizal Symbiosis. Academic Press. 787 pp.

Sundram, S (2010). Growth effects by arbuscular mycorrhiza fungi on oil palm seedlings (Elaeis guineensis Jacq.). J. Oil Palm Res. Vol. 22: 796-802.

Sundram, S (2013). The effects of Trichoderma in surface mulches supplemented with conidial drenches in the disease development of Ganoderma basal stem rot in oil palm. J. Oil Palm Res. Vol. 25: 314-325.

Sundram, S; Abdullah, F; Ahmad, Z A M and Yusuf, U K (2008). Efficacy of single and mixed treatments of Trichoderma harzianum as biocontrol agents of Ganoderma basal stem rot in oil palm. J. Oil Palm Res. Vol. 20: 470-483. 
Sundram, S; Angel, L P L; Tay, B Y P; Roslan, N D; Mohamed Azni, I N A and Idris, A S (2016). Trichoderma virens, an effective biocontrol agent against Ganoderma boninense. МРOB Information Series No. 587: 4 pp.

Sundram S; Meon, S; Idris, AS and Othman, R (2011). Symbiotic interaction of endophytic bacteria with arbuscular mycorrhizal fungi and its antagonistic effect on Ganoderma boninense. The J. Microbiology, 49: 551.

Sundram S; Meon, S; Idris, A S and Othman, R (2015). Application of arbuscular mycorrhizal fungi with Pseudomonas aeruginos UPMP3 reduces the development of Ganoderma basal stem rot disease in oil palm seedlings. Mycorrhiza, 25: 387-397.

Syura, A M and Tsan, F Y (2008). The impact of organic fertilizer application to oil palm production in FELDA Maokil 7: A case study. Proc. of the International Plantation Industry Conference and Exhibition. Kota Kinabalu, Sabah. https://www. iipm.com.my / ipicex2014/ docs/ posters / Asy\%20 Syura\%20and\%20Tsan.pdf, accessed on 17 May 2019. 8 pp.

Tarmizi, A M and Mohd Tayeb, D (2006). Nutrient demands of Tenera oil palm planted on inland soils of Malaysia. J. Oil Palm Res. Vol. 18: 204-209.

Teo, L; Muhammad Shukri, R; Ong, K P and Zainuriah, A (2010). Alternative oil palm fertilizer sources and management. Oil Palm Bulletin No. 61: 11-32.

Thuler, D S; Floh, E I S; Handro, W and Barbosa, H R (2003). Plant growth regulators and amino acids released by Azospirillum sp. in chemically defined media. Letters in Applied Microbiology, 37: 174-178.

Turner, T R; James, E K and Poole, P S (2013). The plant microbiome. Genome Biology, 14: 209.
Vargas, W A; Djonovic, S; Sukno, S A and Kenerley, C M (2008). Dimerization controls the activity of fungal elicitors that trigger systemic resistance in plants. J. Biological Chemistry, 283: 19804-19815.

Veloo, R; Ranst, E V and Selliah, P (2015). Peat characteristics and its impact on oil palm yield. NJAS - Wageningen J. Life Sciences, 72-73: 33-40.

Velthof, G L; Lesschen, J P; Webb, J; Pietrzak, S; Miatkowski, Z; Pinto, M; Kros, J and Oenema, O (2014). The impact of the nitrates directive on nitrogen emissions from agriculture in the EU-27 during 2000-2008. Science of the Total Environment, 468-469: 1225-1233.

Vimal, S R; Singh, J S; Arora, N K and Singh, S (2017). Soil-plant microbe interactions in stressed agriculture management: A review. Pedosphere, 27: 177-192.

Woittiez, L S; Wijk, M T; Slingerland, M; Noordwijk, M and Giller, K E (2017). Yield gaps in oil palm: A quantitative review of contributing factors. European J. Agronomy, 83: 57-77.

Yahya, Z; Husin, A; Talib, J; Othman, J; Ahmed, O $\mathrm{H}$ and Jalloh, M B (2010). Soil compaction and oil palm (Elaeis guineensis) yield in a clay textured oil. American J. Agricultural and Biological Sciences, 5: 15-19.

Yan, X and Gong, W (2010). The role of chemical and organic fertilizers on yield, yield variability and carbon sequestration-results of a 19-year experiment. Plant Soil, 331: 471-480.

Zahran, H H (1999). Rhizobium-legume symbiosis and nitrogen fixation under severe conditions and in an arid climate. Microbiol Mol. Biol. Rev., 63: 968-89.

Zulkifli, H; Halimah, M; Chan, K W; Choo, Y M and Mohd Basri, W (2010). Life cycle assessment for oil palm fresh fruit bunch production from continued land use for oil palm planted on mineral soil (part 2). J. Oil Palm Res. Vol. 22: 887-894. 